\title{
The life cycle of sustainable eco-tourism: a Kazakhstan case study
}

\author{
T. I. Mukhambetov, G. O. Janguttina, U. S. Esaidar, \\ G. R. Myrzakulova \& B. T. Imanbekova \\ Almaty Technological University, Kazakhstan
}

\begin{abstract}
This article is devoted to some theoretical, methodological and practical aspects of sustainable eco-tourism.

In the theoretical part of the paper it is noted that in the CIS the term "sustainable tourism" is rarely used and the more common term "Ecotourism" is most familiar. This article analyses the similarities and differences between them as well as other close and related "isms" within the meaning of the definitions: "Moral tourism", "Nature tourism", "Green tourism", "Responsible Tourism".

According to the authors, "Sustainable Tourism" is not a kind of tourism. The characteristics of the listed types of tourism all have certain indicators associated with sustainable tourism. From this perspective, we can talk about eco-tourism as a pillar of sustainable tourism.

In the practical part of the paper the authors give a general characterization of tourism in Kazakhstan. It analyses the problems encountered in the formation and development of ecological tourism. Based on a comprehensive analysis it concludes that tourism in Kazakhstan is not developed nor is there the political will to adopt a common organizational approach to the development of sustainable eco-tourism.

In the methodological part of the paper, the authors develop the most important aspect - the "life cycle of the tourism product", particularly its sustainability.

The authors demonstrate its features, allocate life cycle stages and discuss the causes and factors contributing to the rate of aging of the product. One example of eco-tourism in Kazakhstan shows that some Kazakhstan ecotourism products require urgent measures to prolong their life cycle, which will be beneficial to all participants in the tourism industry.
\end{abstract}

Keywords: tourism in Kazakhstan, sustainable tourism, eco-tourism in Kazakhstan, the life cycle sustainable eco- tourism product. 


\section{Introduction}

The term "sustainable tourism" in Kazakhstan is rarely used at any level and will not be familiar to most. The State Tourism Development Program uses the term "Eco-tourism", but this is only being developed through the efforts of USAID and several other non-governmental organizations.

However, the question is whether the present state of the industry adequately meets the expectations associated with the terms "ecological tourism" and "sustainable tourism"? What are the differences between these and many other similar ones within the meaning of the terms? Can we assume that sustainable tourism takes place in Kazakhstan? What is the situation and what are the prospects for sustainable tourism in Kazakhstan? Which factors affect the product life cycle of sustainable eco-tourism? At what stage of the life cycle of eco-tourism are tourist products in Kazakhstan? What affects them? These and other questions need to be answered in order to build the future strategy of tourism development and the maintenance of tourist destinations in Kazakhstan.

\section{Terminology of sustainable tourism}

In Kazakhstan, as well as in the CIS countries as a whole, the term "sustainable tourism" is not appreciated and is almost unknown to most. It is not even used at the government level and would not seem to have a place in other sectors of tourism development.

Also rare, but you can find similar and related terms "Responsible Tourism", "soft tourism", "moral tourism", "Nature tourism" as well as "green tourism". With so many terms, concepts and definitions, often interconnected with each other, it is not surprising that few people understand the differences between them. In the recent past there were clear differences between the different types of tourism, but now the boundaries are becoming increasingly blurred.

In many ways, this can be attributed to the English-language literature, as well as to international organizations, all of which have contributed a number of terms with similar meanings. Each of them gives its own definition of sustainable tourism the differences between which are not always clear even to specialists in the field. Some of the scholars consider them as separate types of tourism, others see them as mutually overlapping concepts or as components of each other.

Mexican economist and ecologist Hector Tsebalass-Laskureyn first coined the term "ecological tourism", and defined it as a journey with responsibility to the environment in relatively undisturbed natural areas to explore and enjoy nature and cultural attractions. Ecotourism, as he says, contributes to the protection of nature, makes a "soft" impact on the environment, and provides for an active socio-economic involvement of local people that enables them to receive the benefits of this activity (Ceballos-Lascurain [1]). This is the classic definition of eco-tourism, although, a scholar such as Matthews [2] identifies seven characteristics of ecotourism. 
What is the difference between the terms "Ecotourism" and "Sustainable Tourism"?

Fennell and Dowling [3], when listing standards of ecotourism, include sustainability. Thus, they include sustainability of the eco-tourism as one of its properties.

However, the more common view is that ecotourism is an integral part of sustainable tourism (Sâmbotin et al. [4], Bansal and Kumar [5]).

Indeed, sustainable tourism aims to provide three key target indicators:

- Quality - tourism should have an impact on the quality of life for all members of the tourist process;

- Optimality - exploitation of natural resources should be optimal and ensure their regeneration;

- Balance - distribution of benefits among participants in the tourist process must be fair.

From this perspective, sustainable tourism is not a type of tourism, but a kind of unifying concept that includes different types of tourism that are linked with the use of natural places, parks and protected areas. These qualities have the character of sustainable tourism, when they combine to provide quality and optimal balance. "Eco-tourism" and "Nature tourism" are separate types of tourism. At the same time, terms such as "Responsible Tourism", "soft tourism", "A moral Tourism" and "Green Tourism" are simply different names for these types of tourism. They reflect the various aspects of ecological tourism.

Sustainable tourism is the goal that must be advanced in any kind of tourism, despite the fact that it is rarely achieved. Sustainable tourism does not imply a specific set of events. This is more than an approach that aims to express itself in all sectors of tourism. This is a natural extension of the concept of sustainable development. Sustainable development - the development that meets the needs of the present without disrupting the ability of future generations to meet their own needs (IISD [6]).

The concept of sustainability was first proposed in the report of the World Commission on Environment and Development in 1987, in which it was noted that economic growth and environmental conservation should be carried out in unity. This development satisfies the needs of the present without compromising the ability of future generations to meet their own needs (IISD [6]).

Sustainable tourism implies a much greater social responsibility, fulfillment of obligations in relation to nature, as well as the involvement of local people in all processes related to the management of tourism activities.

World Tourism Organization (WTO [7]), the World Council of Travel and Tourism (WTCC [8]) gave the definition of sustainable tourism. Sustainable tourism development satisfies the needs of present tourists and host regions while protecting and enhancing opportunities for the future. Management of all resources must be exercised so that they meet the economic, social and aesthetic needs, but also protect the cultural integrity, essential ecological processes, and biological diversity and life support systems. 
The concept of sustainable tourism is not widely accepted in the CIS countries, mainly because most of these countries are not familiar with the concept, with the result that it is weakly correlated with the management of the raw material economy.

Nevertheless, Kazakhstan in 2012 took over the fashionable concept of "green economy", similar to the ideas of sustainable development. However, this concept as appears to be an independent branch of the economy. It is at least, but is not dominated by, the idea of maximum conservation for future generations and by minimizing damage to nature. Green economy, rather, is based on technological projects of alternative energy and energy efficiency of the economy. It does not focus on environmental pollution in some sectors (e.g. oil), but it is actively developing environmentally friendly technologies in other sectors (energy, water, etc.).

Nevertheless, in our opinion, you can use the term "green tourism", implying not only eco-tourism, but in general any tourism based on the principles of sustainable tourism. This is a kind of adaptation to the political context in which the political coloring becomes more important when the essence and importance of the term "sustainability" is used in all other terms. In this case, the term "Green" ("Green Transportation", "Green Energy", "Green University", "Green House", etc.)

\section{Tourism in Kazakhstan}

The structure of the flow of Kazakhstan tourism is typical for most of the CIS countries, where outbound tourism is most intensive. Flows of outbound tourism grew and continue to grow over the years. The balance of Kazakhstan tourism is decidedly negative with more than 500 million dollars in favor of outbound tourism in 2012. Kazakhs prefer beach, shopping and visit holidays in Turkey, China, United Arab Emirates, the Kingdom of Thailand and other countries.

In real terms, the share of inbound tourism, however, remains high. In 2012, the share of inbound tourism constituted $31.4 \%$ of total tourism revenues, whilst outbound made up $50 \%$ and domestic tourism less than $18.6 \%$. The number of foreign nationals who had entered Kazakhstan was 6163 thousand people. However, of these 5542 thousand were citizens of the CIS. In other words - it is a working tourism - people who came to work from Uzbekistan, Kyrgyzstan and other Central Asian republics (Turism [9]).

From the remaining 620 thousand visitors, foreign tourists who entered for private purposes accounted for $80 \%$, and transit travelers for $13 \%$. The remaining $7 \%$ was made up of business travel and leisure and recreation, or slightly more than 43000 people. This is an extremely low figure, indicating that Kazakhstan has not yet become an attractive country for pure tourism. It is not surprising that hotel occupancy in 2012 was only $25 \%$.

Share of GDP is about 2 percent. For comparison, in developed countries this figure reaches 30 percent. Reasons for the low attractiveness of Kazakhstan for many foreign tourists: low country marketing, low attractiveness of tourist objects that do not represent a high cultural and historical value in comparison 
with world objects, a huge distance to nature reserves, lagging service sector, high prices for services.

In general the country, despite the presence of a government agency to adopt a state program for the development of tourism, still misses a holistic approach to tourism development. This is evident in the unrelated development of different branches of tourism.. The recent trend has been the focus of attention on the development of the state space tourism (Baikonur Cosmodrome), the development of the capital Astana as a center for business tourism. As it happens, time will tell. These initiatives have been many albeit unsuccessful.

At the same time it is accepted that attempts have been made to expand the participation of Kazakhstan in international exhibitions, the opening of tourist information centers at the airport and in the largest city Almaty. However, the city remains environmentally dirty and urban infrastructure is not designed to attract foreign visitors (traffic jams, noise, poor public transport, lack of inscriptions in English, etc.).

In the whole country there are certain prerequisites for the development of ecological tourism that are missing.

In the state are nature reserves and national parks, several thousands of archaeological and historical monuments of different historical and cultural value. The most popular and visited are the natural parks and reserves: Burabai, Bayanaul, Korgalzhyn reserves, Kolsai Lake, Bukhtarma reservoir, Lake Alakol, Charyn Canyon, Ile-Alatau National Park, etc. But many of them, such as the island Araltobe Canyon Zhamanty lake Zhalanashkol, Zhabyktau and many others are almost impossible to visit. These are almost no roads, nearby infrastructure and people's homes.

Among cultural monuments can list the Mausoleum of Khoja Ahmed Yassaui mausoleum Arystan Baba, Otrar.

As already mentioned, in 2003, several international NGOs funded the project implementation of the principles of eco-tourism in Kazakhstan. Since then, to some extent the country began to use the term "Eco-tourism" and undertook certain work. In particular the framework of this project involved the creation of ecosites 15 (Ecotourism [10]).

To call them ecosites is difficult because an ecosite in international practice involves villages where residents take guests under the concept of rural ecotourism. In Kazakhstan - there are about 50 families living in 25 villages in Kazakhstan. The cost of living in these villages is quite high: about $\$ 50$ per day, which usually includes accommodation, meals and outdoor bathrooms.

The State Program on development of tourism in the Republic of Kazakhstan eco-tourism has been recognized as one of the priority directions for the development of tourism in the country. But, despite the fact that this program was adopted in 2006, Kazakhstan has not formulated unified organizational policies and approaches to the development of ecotourism.

In practice eco-tourism is associated with tourists visiting protected areas and rural areas, the increase in national and international flows of tourists and the associated development of tourism infrastructure in these areas. However, in fact, sustained eco-tourism - it is not mass tourism, and it is not intended to 
support large flows of tourists to natural areas. In this sense, it is an alternative to this approach. It is aimed at the preservation of nature while offering the benefits of tourism to the local population (Ni et al. [11]).

\section{The life cycle of sustainable eco-tourism product}

The concept of life cycle applies to the tourism product as well as to any commercial product. Plog [12] identified three kinds of tourists (allocentric, midcentric and psychocentric) whose psychology and preferences conditioned the rise and fall of destinations. However, the most widely accepted and discussed model was proposed in 1980 by Butler which represented an adaptation of the life cycle model to the destination context. In the longitudinal analysis, changes in tourist destinations have been considered as elements of the different stages they pass through in time. The life cycle model (Butler [13]) proposed a hypothetical evolution of a tourist area, and suggested that destinations pass through six stages (Exploration, Involvement, Development, Consolidation, Stagnation, Decline and Rejuvenation)

Using the category of "The life cycle sustainable eco-tourism product" is particularly important. The fact is that the meaning of sustainable tourism is to cause minimum damage to nature and to preserve it for future generations. In other words, this means that the priority of a sustainable tourism product is to have a long life cycle, and the actual length of the product life cycle is the criterion of the principles and objectives of a sustainable ecological tourism product.

Sustainable tourism in contrast to the usual eco-tourism product has its own peculiarities.

The World Tourism Organization has identified the objectives of ecotourism:

1. Ecotourism should assist in the protection and conservation.

2. Ecotourism should help create jobs, and in a way - additional income for local communities.

3. Ecotourism should help to increase knowledge and awareness about the local culture.

4. The aim of eco-tourism is to teach tourists. That is, sustainable tourism should provide educational influence on tourist increase its awareness of sustainable development issues and promote sustainable tourism practices (WTO [7]).

We would add the following features.

1. Sustainable tourism implies the maximum use of "green technologies" in its process ("green energy", "green food", "green home", etc.).

2. Sustainable tourism as opposed to mass tourism, is largely a personalized tourism aimed at promoting ecology and conservation. 
3. Sustainable tourism requires conscious participation of all stakeholders, as well as strong political leadership to ensure wide participation and consensus (Hall [14]).

4. Sustainable tourism requires continuous monitoring of the human impact on nature presenting the necessary preventative and/or corrective measures whenever necessary (Kiper [15]).

These and other features are making adjustments to the understanding of the life cycle of the tourism product.

Violation of these features and the rules leads to a drop in eco-tourism product life cycle. Distortion occurs when the idea of sustainable tourism transforms into the usual tourist product of mass consumption.

\section{Problems of sustainable eco-tourism in Kazakhstan and maintaining its life cycle}

As we mentioned above, the concept of sustainable tourism is not widespread in Kazakhstan. Eco-tourism is largely related to sustainable tourism but is also not the dominant type of tourism in Kazakhstan.

Tour operators in Kazakhstan have recently started to use the prefix (brand) "eco", to attract visitors, as it significantly increases the price of the tour.

Completion of the mentioned project for the development of ecological tourism in Kazakhstan has also reduced the development of the principles of ecotourism. Thus, curtailment eco-tourism, in fact, led to a rapid reduction in their life cycle. What difficulties and obstacles exist to prevent the implementation of the principles of sustainable tourism and the support life cycle for sustainable eco-tourism in Kazakhstan?

Minor amounts of unique natural objects led to the fact that, in practice, ecological tours were established on the basis of existing tours and routes of mass tourism. It is very difficult to follow the principles of sustainable tourism, where the mass tourist routes pass. In such cases, tourists who came to enjoy wildlife, see foot-worn paths and traces of mass or, as it is called in Russian, "wild" tourists in the form of numerous hearths (remains of the bonfires), mountains of garbage etc.

All available routes in Kazakhstan were developed in the Soviet era. One of the authors of this article went on many of them in the early 90s. At that time they were in a more natural state due to the fact that the numbers of people who went on them were much less than is the case today.

Ecosites were placed in the same villages where through which the mass tourist passes. Improving the living standards of the local population leads to their turning into the domestic "wild" tourist, traveling by the car through the same sites, which are trying to develop eco-tourism. Self-organized domestic tourists in cars usually drive up close to objects of tourism. Basically, the vehicle can reach most of them. They come with their families and friends, bring with them a huge amount of food, arrange bonfires, spread litter and sing songs. 
In this form you can see the main tourist destinations, which are in protected areas and parks: Turgen and Turgen waterfalls, Canon Charyn, Kolsai Lake, Lake Alakol, Bayanaul, State national natural park "Kokshetau" Tamgali and Tambaly and Tas. Kazakhstan has a short beach holiday and swimming season which is why wild "outdoor recreation" is one of the most common forms of spending free time. It has no relation to eco-tourism, but is practiced on the territory of ecological tourism.

It is implemented where the principal beneficiaries of eco-tourism are the locals? The fact is that the residents of the villages located near the natural parks and protected sites receive more income from the mass tourist than from the ecological rare guest and therefore cannot wait for the latter. The mass tourist is more profitable and can be a major source of income for the villager. In this case, locals have also contributed to the increased pressure on nature together with the "wild tourist."

One of the reasons for low ecological orientation of tourism is the weak activity of the Government to promote the ideas of ecological tourism. Officials perceive psychologically sustainable and eco-tourism as a costly and troublesome initiative.

No indicative planning and monitoring of the development of ecological tourism. Statistics and records of tourism is one of the main problems in the development of tourism. Thus, according to official numbers domestic tourism in 2012 was covered by 201 thousand people [9]. But these numbers are highly questionable, as domestic tourism has the character of weekend tours and "wild tourism". Wild tourists are weakly identifiable and can be considered only based on the number of tickets sold at the entrance to the natural park or ecological reserve.

However, there are places where turnpikes are subject to corruption and unaccounted cash, and therefore no reliability can be placed on their accounting of who came to visit. In fact, according to our estimates, the number of domestic tourists is not less than 2 million people a year. Naturally, this mass tourism sector significantly exceeds the number of eco-tourists, the number of which is not known to anyone. Local residents in these conditions will always be focused on the "wild" mass tourists, reducing even more the life cycle of sustainable tourism.

In the places of eco-tourism "green technologies" such as solar cells, biological water purification, etc. are absent .The cottages and houses are built close to the objects (e.g. Kolsai Lake), and electricity and electric poles surround every house and cottage. Can accommodation in yurts (ethnic house of felts), be considered as eco-tourism if it is located next to modern cottage homes?

The state does not pay enough attention to the development of ecotourism and solving its problems.

These factors significantly reduce the life cycle of sustainable tourism product. This product will always lose mass tourist product. Since the beginning of its launch such a product will quickly collapse and interest in it will decline on all sides of the tourist process. Consumer (tourist) will not get satisfaction, a 
local resident will be oriented to the mass tourist and nature will continue to be polluted. Eventually the product will close.

In Kazakhstan, we are fond of saying that there is a huge potential for tourism development. It is difficult to agree with this when even the existing tourism facilities are not used as efficiently as possible.

As we have shown, there are many problems in the field of tourism, especially eco-tourism. As a result, there is no optimal resource consumption, which violates the principle of sustainable tourism. Natural parks are choking on the influx of informal local tourists, their litter and noise. It is hardly possible to talk about biodiversity in such cases. For example, at the entrance to the reserve of Bayanaul standing sculptures of birds can be seen along the road. Eagles, swallows and larks once lived here flying freely in the sky. But since the 80s there are none. What influenced their disappearance: radiation from a nearby Semipalatinsk nuclear test site, or noise from "wild" tourists coming to the bosom of nature to relax for the weekend is difficult to judge. But now there are only flying crows and sparrows.

Disappointment also engulfs one when visiting places of rock inscriptions such as Tamgaly Tas, when one sees see inscriptions of modern people "Here was Aydin" adjacent to the drawings of ancient people.

\section{Fields of activities to increase the life cycle of sustainable tourism}

The Government of the Republic of Kazakhstan in 2013 discussed the concept of tourism industry development until 2020 but this is still not accepted. As far as we know, insufficient attention is once again paid to sustainable tourism, although the concept of regional clusters is highlighted.

In accordance with this concept of an eco-tourism zone in Eastern Kazakhstan, is planned with the development of the Katonkaragay zone and the West Altai Mountains. Almaty and Almaty region will ensure the development of skiing and urban tourism. On the territory of South Kazakhstan region, Kyzylorda and Zhambyl regions planned to create cultural tourism. West Kazakhstan becomes a zone of beach tourism to the city center that Kenderli on the beach in the city of Aktau and adventure tourism.

Such a concept of the cluster approach is more balanced. But it also has certain disadvantages.

Show the main ways to increase the life cycle of sustainable tourism product on the example of Kazakhstan.

To develop eco-tourism in the cluster basis is not enough of the right approach. Sustainable tourism - is not the kind of tourism, like the beach or cultural and historical tourism. This kind of philosophy for tourism pays careful attention to any object, including objects like the beach, historical or any other kind of tourism. Therefore, a regional approach to its development is not applicable. Otherwise, such an approach would be to store objects of tourism in this region and in other regions of ruin. Thus, a sustainable approach should be 
defined in the Concept as a political statement, as a general approach to the development of tourism in general.

Eco-tourism will benefit if the domestic tourist goes to the principles and rules of eco-tourism. And only when the environment is restored and all routes will be audited, classified into categories of tourism and there are special routes and ecotours. These ecotourism routes must be protected from environmental patrol mass tourism and based on the principles of sustainable tourism, best avoided.

For classification and identification of environmental routes in all regions of Kazakhstan, you must first calculate the potential capacity for sustainable tourism.

Middleton and Hawkins give the definition of tourist capacity of tourism as the level of human activity, which can be implemented on the site without harming the area without affecting the local community, and the quality does not deteriorate stay visitors (Middleton and Hawkins [16]).

UNEP proposed the following definition of tourism capacity as the maximum number of people who can visit the destination at the same time, without causing destruction of the physical, economic and socio-cultural environment and an unacceptable decrease in the quality of visitor satisfaction (UNEP [17]).

According to our calculations, the total capacity of ecological routes of Kazakhstan is approximately 50,000 visits per year. Increase in load will reduce the life cycle of sustainable tourism products. In fact, these routes are currently experiencing at least 10 times greater. This means that ecological routes of Kazakhstan are in a state of decay, and they will not grow, as they will become definitively a product of mass tourism.

We should carry out certification and Ecological Monitoring of routes and expose the annual assessment of the negative impact of tourism on local resources such as energy, fauna, flora, land, water. Environmental labeling will identify routes and amount of state financial assistance to eco-tours.

\section{Conclusions}

Currently, in terms of sustainable tourism uncertainty persists. Their analysis allowed us to determine the stability of the resulting quality as the final, which should seek forms of tourism such as "sustainable tourism", "eco-tourism". From this perspective, the concept of eco-tourism in the sustainable tourism is preferable to determine how sustainable eco-tourism is.

Analysis of the development of sustainable tourism in Kazakhstan showed that international inbound tourism in the country has a weak pace of development. Eco-tourism has a number of problems associated with the lack of attention the government gives to this type of tourism, a violation of the basic principles of ecotourism. As a result, product life cycle is short of eco-tourism, and this type of tourism is on the stage of rapid decline.

Dedicated reasons for the reduction of product life cycle eco-tourism should be allowed to make recommendations that will contribute to the revival of ecological tourism in Kazakhstan. Among them: strengthen state regulation, to 
introduce eco patrol, inspection and certification of tourist routes ecological routes, enter state support ecotourism monitoring using key indicators, etc.

\section{References}

[1] Ceballos-Lascurain H. Introduction: Ecotourism as a Worldwide Phenomenon. In Ecotourism: A Guide for Planners and Managers (K. Lindberg, D. Hawkins, Eds.). The Ecotourism Society, Alexandria, Va, USA: 1-3, 1993.

[2] Matthews E. J, Ecotourism: Are Current Practices Delivering Desired Outcomes? A comparative case study analysis Major Paper submitted to the Faculty of the Virginia Polytechnic Institute and State University in partial fulfilment of the requirements for the degree of Master of Urban and Regional Planning in Urban Affairs and Planning. 106, 2002.

[3] Fennell D. A, Dowling R. K, Ecotourism Policy and Planning CABI Publishing: Oxon and Cambridge, 2003.

[4] Sâmbotin D, Sâmbotin A, Pătrăşcoiu M, Coroian A, Mercel I. I, Ecoturismul - Model de Valorificare Durabilă a Resurselor Turistice, Lucrări Ştiinţifice, Seria I, Vol. XIII (4). 2011.

[5] Bansal S. P, Kumar J, Ecotourism for Community Development: A Stakeholder's Perspective in Great Himalayan National Park. International Journal of Social Ecology and Sustainable Development, 2(2), 31-40. 2011.

[6] IISD, What is Sustainable Development? International Institute for Sustainable Development, IISD, 2012.

[7] WTO, http://www.world-tourism.org

[8] WTTC, http://www.wttc.org

[9] Turism Kazakhstana 2008-2012. Agentstvo Respubliki Kazakhstan po statistike, 2013.

[10] Ecotourism, http://www.eco-tourism.kz

[11] Ni V., Mirhashimov I., Klimov E., Tonkobayeva A. Rukovodstvo po razvitiyu ecologicheskogo turisma v Kazakhstane. Almaty, 2009.

[12] Plog S.C. Why destinations areas rise and fall in popularity Cornell Hotel and Restaurant Association Quarterly, 13, 6-13, 1973.

[13] Butler, R.W. The concept of the tourist area life-cycle of evolution: implications for management of resources. Canadian Geographer, 24 (1), $5-12,1980$.

[14] Hall C.M., Tourism Planning: Policies, Processes and Relationships. nd Edn., Pearson/Prentice Hall, Harlow, England, New York, 2008.

[15] Kiper T. Role of Ecotourism in Sustainable Development, in "Advances in Landscape Architecture”. Ed. by Murat Özyavuz, Intech. 2013.

[16] Middleton V.C., Hawkins, R. Sustainable Tourism: a marketing perspective Butterworth-Heinemann, 1998.

[17] United Nations Environment Program Eco-labels in the tourism industry. UNEP Industry and Environment, Paris, 1998. 